\title{
SUPPLEMENT TO THE \\ UMTRA PROJECT WATER SAMPLING \\ AND ANALYSIS PLAN \\ SLICK ROCK, COLORADO
}
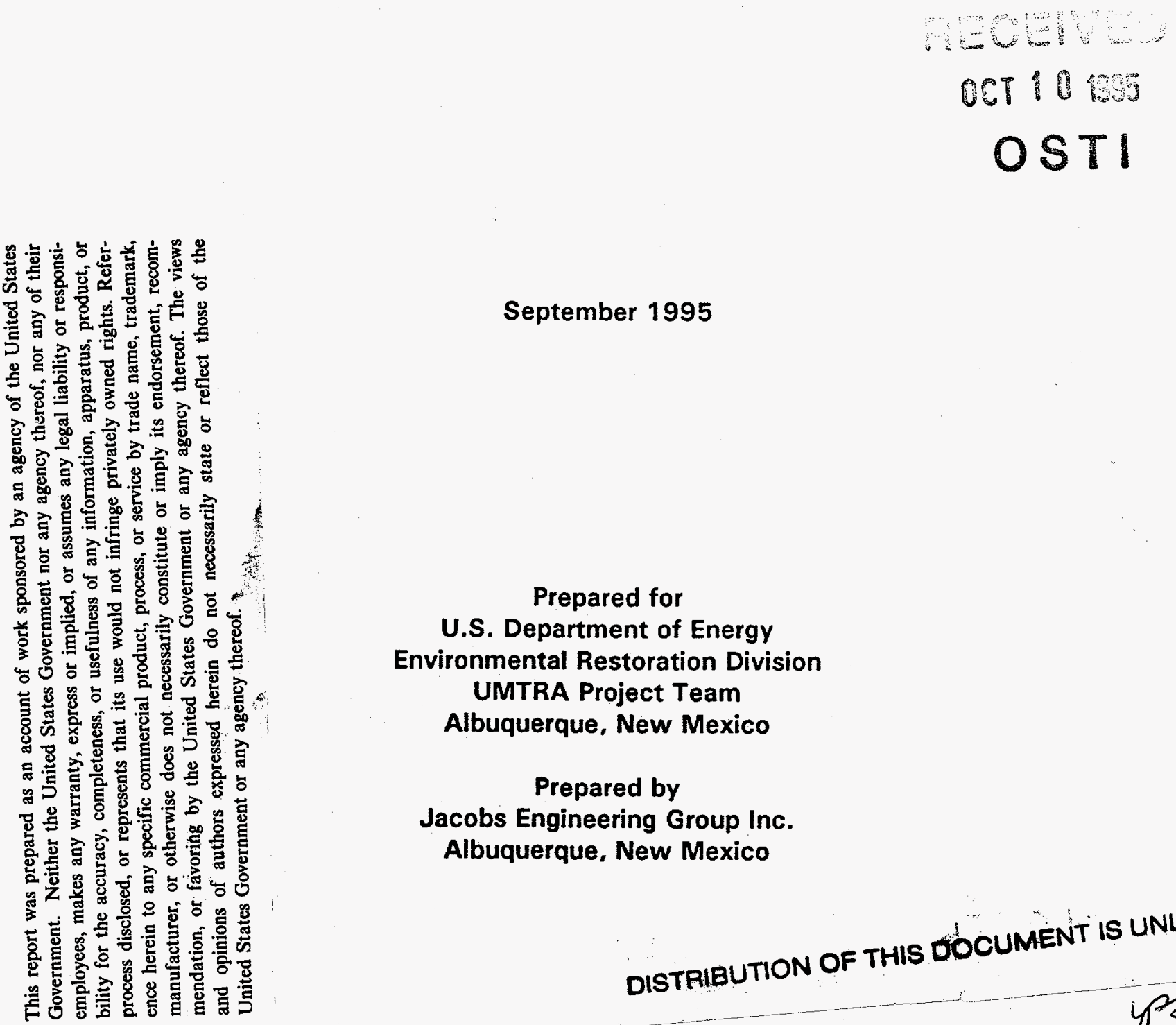

September 1995

Prepared for

U.S. Department of Energy

Environmental Restoration Division

UMTRA Project Team

Albuquerque, New Mexico

Prepared by

Jacobs Engineering Group Inc.

Albuquerque, New Mexico

DISTRIBUTION OF THIS DOCUMENT IS UNLIMITED
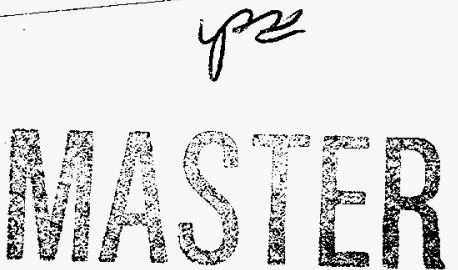


\section{DISCLAIMER}

Portions of this document may be illegible in electronic image products. Images are produced from the best available original document. 


\subsection{INTRODUCTION}

The water sampling and analysis plan (WSAP) provides the regulatory and technical basis for ground water and surface water sampling at the Uranium Mill Tailings Remedial Action (UMTRA) Project Union Carbide (UC) and North Continent (NC) processing sites and the Burro Canyon disposal site near Slick Rock, Colorado. The initial WSAP was finalized in August 1994 and will be completely revised in accordance with the WSAP guidance document (DOE, 1995) in late 1996. This version supplements the initial WSAP, reflects only minor changes in sampling that occurred in 1995, covers sampling scheduled for early 1996, and provides a preliminary projection of the next 5 years of sampling and monitoring activities.

Once surface remedial action is completed at the former processing sites, additional and more detailed hydrogeologic characterization may be needed to develop the Ground Water Program conceptual ground water model and proposed compliance strategy. In addition, background ground water quality needs to be clearly defined to ensure that the baseline risk assessment accurately estimated risks from the contaminants of potential concern in contaminated ground water at the UC and NC sites.

\subsection{SITE DESCRIPTION}

The UMTRA Project UC and NC uranium mill tailings sites are located near the small community of Slick Rock, in San Miguel County, Colorado (Figure 1). Both sites are adjacent to the Dolores River. The UC processing site is approximately 1 mile (mi) (2 kilometers [km]) downstream from the NC processing site. The surface remedial action consists of relocating, disposing, and stabilizing the contaminated materials from the former processing sites into a permanent repository at the Burro Canyon disposal site. The disposal site is approximately 6 road mi $(10 \mathrm{~km})$ northeast of the mill sites (Figure 1).

For a more detailed discussion of the location, history, site conceptual model, and water sampling plan procedures for the Slick Rock processing sites and Burro Canyon disposal site, see the WSAP (DOE, 1994a).

\subsection{SLICK ROCK PROCESSING SITES}

Water sampling was conducted at the former Slick Rock UC and NC processing sites (SRKO1) in February 1995. Ground water, surface water, and sediment sampling is conducted at the processing sites to ensure protection of human health and environment, define the nature and extent of contamination, monitor ground water compliance prior to the initiation of surface remedial action, and support the findings of the baseline risk assessment of ground water contamination at the former processing sites.

Ground water is sampled at the U.S. Department of Energy (DOE) monitor wells at the Slick Rock mill sites and at private wells in the vicinity. A total of 19 DOE monitor wells are sampled at the locations shown in Figure 2. Table 1 provides the 
rationale for each recommended sampling location. Three nearby private wells are sampled. Table 2 provides a description and rationale for sampling private wells. Both filtered and unfiltered samples are collected from DOE monitor wells and private wells to support the findings of the baseline risk assessment.

The order of sample collection for the DOE monitor wells is based on historical information regarding lowest to highest concentrations of hazardous constituents. Unfiltered private well samples are collected from a drinking water outlet downstream from any private filtering system. When only a limited quantity of water is available, sample collection bottles are prioritized (from highest priority to lowest) in accordance with Section 2.3.1 of the WSAP (DOE, 1994a).

Ground water samples were not collected from DOE monitor wells completed in the Navajo Sandstone at either tailings site in 1995 and will not be collected in the future. Historically, these wells have not shown any contamination, and sufficient data have been collected to characterize water quality.

A total of four surface water samples and four sediment samples are collected along the Dolores River at the Slick Rock sites at the approximate locations shown in Figure 2. Both filtered and unfiltered surface water samples are collected to support the findings of the baseline risk assessment. Table 3 provides a description and rationale for surface water sampling.

The list of constituents monitored in DOE monitor wells and private wells and in surface water and sediment samples is presented in the initial WSAP (DOE, 1994a). This list has been modified to reflect the findings of the baseline risk assessment (DOE, 1994b) and the 1995 water sampling event. Constituents eliminated based on the findings of the baseline risk assessment are barium, boron, chromium, dissolved organic carbon, polonium-210, silica, strontium, total organic carbon, and zinc. In 1995, the results from filtered and unfiltered samples show no significant variations for seven constituents. Therefore, the following constituents are eliminated from future unfiltered samples: calcium, chloride, magnesium, nitrate, potassium, sodium, and sulfate. The current list is presented in Table 4 . Based on results of subsequent sampling events, the list of constituents may be further modified.

Water quality sampling was conducted annually prior to the initiation of surface remedial action construction, and is expected to be conducted at least annually during construction to monitor the effects of surface remedial action. Sampling frequency will then be determined using updated water quality and hydrologic data obtained during surface remedial action, results of the baseline risk assessment, and the ground water characterization program. Sampling frequency and the duration of ground water monitoring will be based on contaminant transport travel times and will account for a time lag after surface remedial action is complete.

Based on the current hydrogeologic information available for the NC and UC processing sites, the linear ground water velocity in the Dolores River alluvium has been estimated to range from 100 feet $(\mathrm{ft})$ per year $\left(0.97 \times 10^{-4}\right.$ centimeters [cm] 
per second) at the NC site to $160 \mathrm{ft}$ per year $\left(1.5 \times 10^{-4} \mathrm{~cm}\right.$ per second) at the UC site (DOE, 1994c). The travel time estimate is expected to be refined further during the UMTRA Project ground water compliance program (Subpart B of 40 CFR Part 192).

\subsection{BURRO CANYON DISPOSAL SITE}

Ground water sampling was not conducted at the Burro Canyon disposal site (SRKO2) during 1995. Sufficient data have been collected at the site to establish background ground water quality conditions. Based on an evaluation of site characterization data, the U.S. Nuclear Regulatory Commission, the DOE, and the Colorado Department of Public Health and Environment have concurred in the determination that a program to monitor ground water is not required because ground water in the uppermost aquifer is limited-use ground water (40 CFR $\$ 192.11$ (e); DOE, 1994c).

No surface water or private well sampling locations exist in the disposal site vicinity.

\subsection{REFERENCES}

DOE (U.S. Department of Energy), 1995. Guidance Document for Preparing Water Sampling and Analysis Plans for UMTRA Sites, DOE/AL/62350-70F, REV. 1 , DOE UMTRA Project Office, Albuquerque Operations Office, Albuquerque, New Mexico.

DOE (U.S. Department of Energy), 1994a. UMTRA Project Water Sampling and Analysis Plan, Slick Rock, Colorado, UMTRA-DOE/AL/62350-146, REV. 0, prepared by the U.S. Department of Energy, UMTRA Project Office, Albuquerque Operations Office, Albuquerque, New Mexico.

DOE (U.S. Department of Energy), 1994b. Baseline Risk Assessment of Ground Water Contamination at the Uranium Mill Tailings Sites near Slick Rock, Colorado, UMTRA-DOE/AL/62350-147, REV. O, prepared by the U.S. Department of Energy, UMTRA Project Office, Albuquerque Operations Office, Albuquerque, New Mexico.

DOE (U.S. Department of Energy), 1994c. Remedial Action Plan and Site Design for Stabilization of the Inactive Uranium Processing Site at Slick Rock, Colorado (Preliminary Final), UMTRA-DOE/AL/62350.21PF, prepared by the U.S. Department of Energy, UMTRA Project Office, Albuquerque Operations Office, Albuquerque, New Mexico. 


\section{CODE OF FEDERAL REGULATIONS}

40 CFR Part 192, "Health and Environmental Protection Standards for Uranium and Thorium Mill Tailings," U.S. Environmental Protection Agency. 


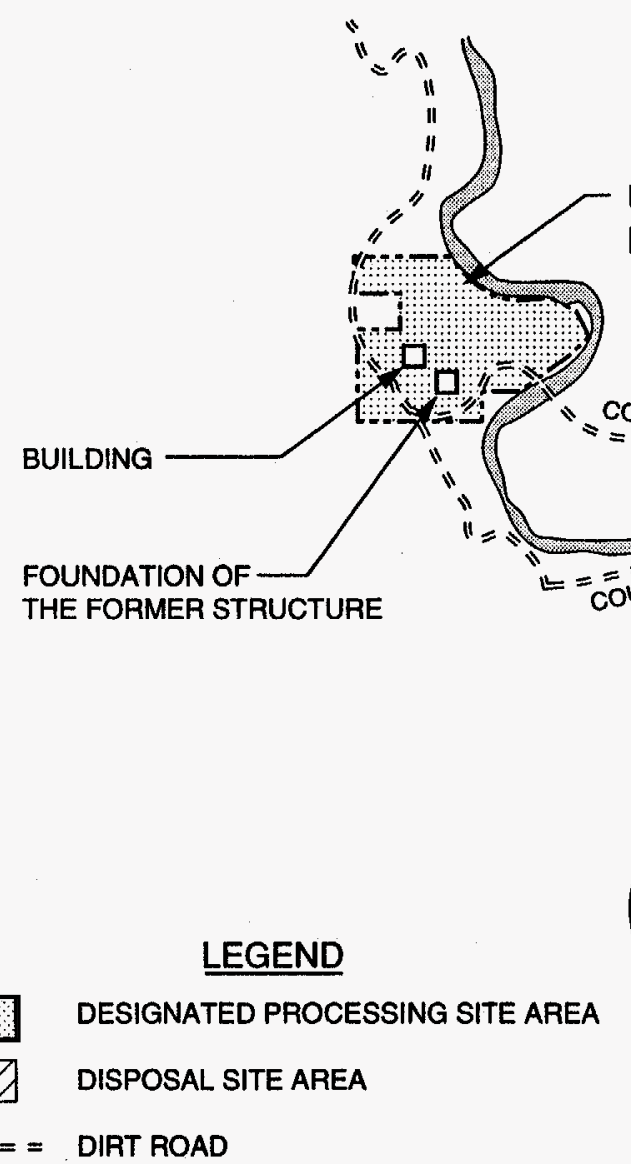

UNION CARBIDE

PROCESSING SITE
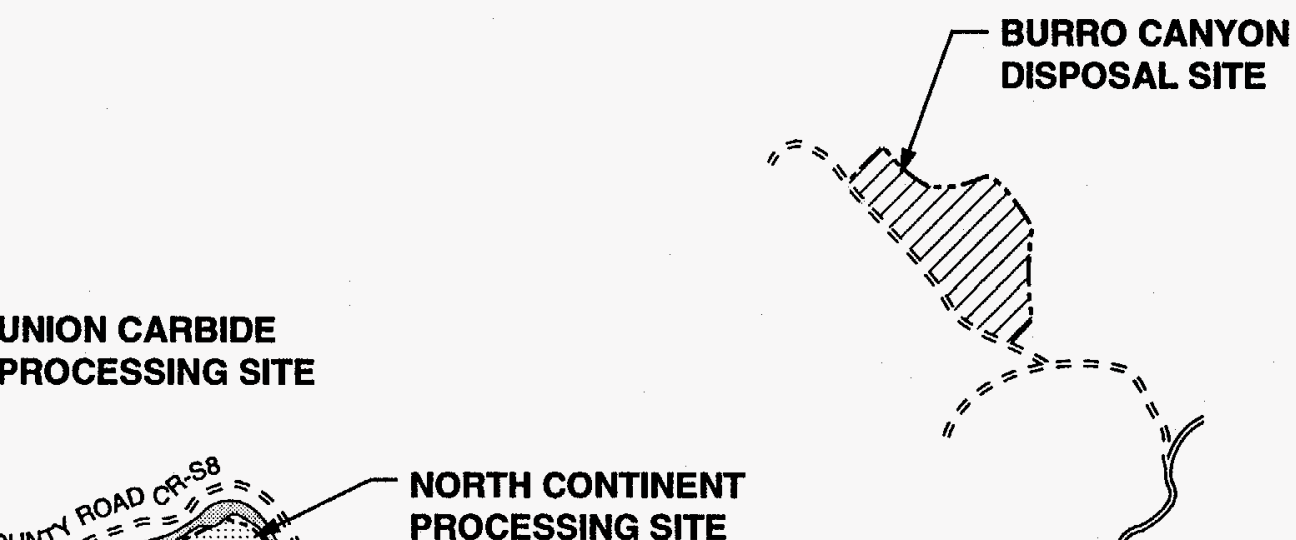

(141) STATE HIGHWAY

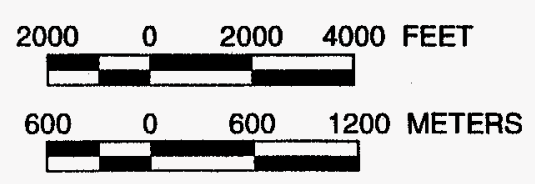

FIGURE 1

LOCATION OF BURRO CANYON DISPOSAL SITE (AND PROCESSING SITES)

NEAR SLICK ROCK, COLORADO 


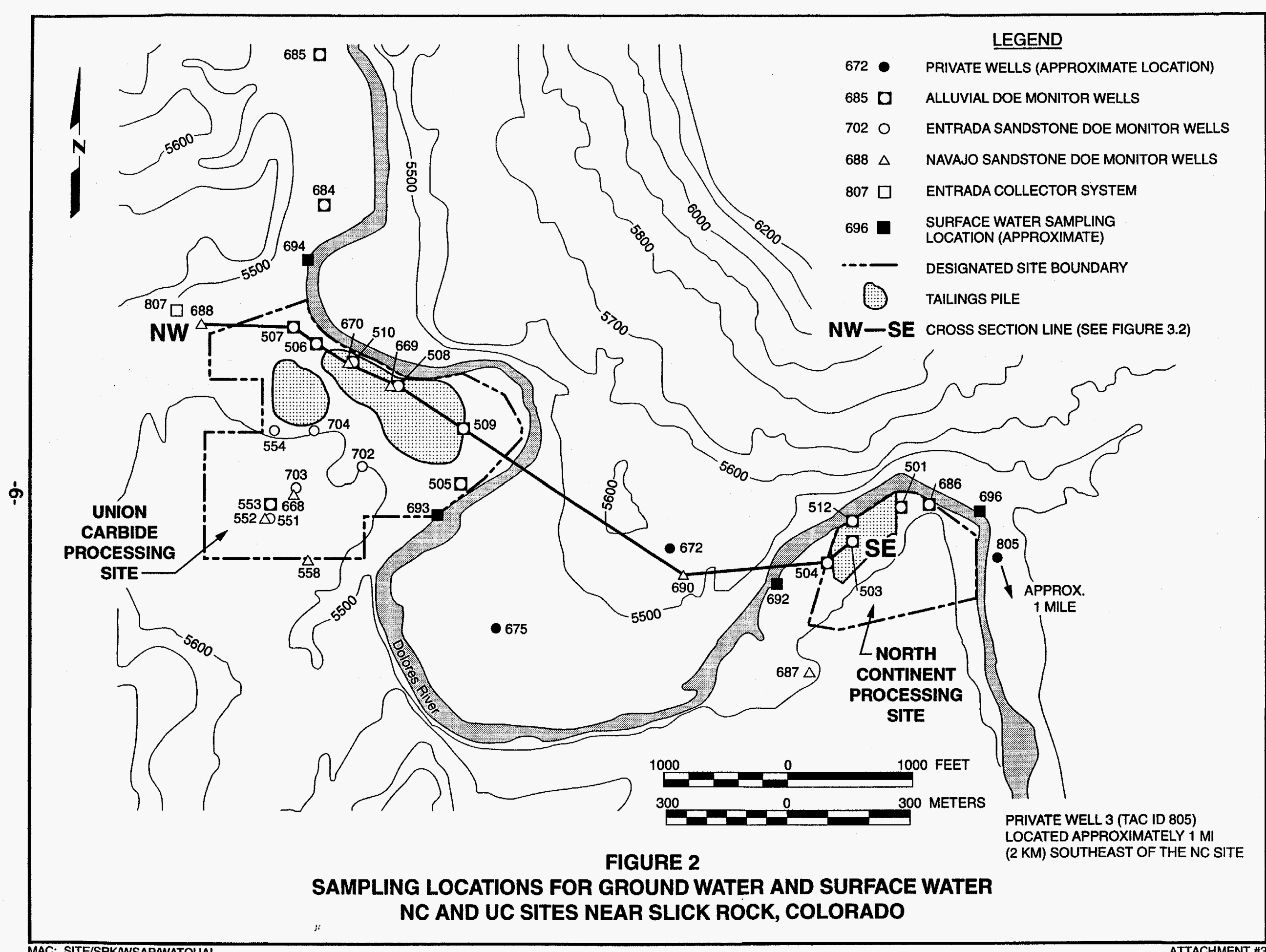


SUPPLEMENT TO THE UMTRA PROJECT WATER SAMPLING

AND ANALYSIS PLAN, SLICK ROCK, COLORADO

Table 1 DOE monitor well sample locations at the former UC and NC sites near Slick Rock, Colorado

\begin{tabular}{|c|c|c|c|c|c|}
\hline Site & $\begin{array}{l}\text { Well ID } \\
\text { (SRK-01) }\end{array}$ & Formation & Location & $\begin{array}{l}\text { Screened } \\
\text { interval }\end{array}$ & Rationale for sampling \\
\hline UC & -0505 & Alluvium & Background & $11.0-19.0$ & $\begin{array}{l}\text { Characterize background } \\
\text { water quality }\end{array}$ \\
\hline UC & -0553 & Alluvium & Background & $12.0-22.0$ & before tailings removal. \\
\hline $\begin{array}{l}\text { NC } \\
\text { NC }\end{array}$ & $\begin{array}{l}-0501 \\
-0686\end{array}$ & $\begin{array}{l}\text { Alluvium } \\
\text { Alluvium }\end{array}$ & $\begin{array}{l}\text { Background } \\
\text { Background }\end{array}$ & $\begin{array}{l}12.0-21.0 \\
15.0 \cdot 20.0\end{array}$ & \\
\hline $\begin{array}{l}\text { UC } \\
\text { UC }\end{array}$ & $\begin{array}{l}-0551 \\
-0703\end{array}$ & $\begin{array}{l}\text { Entrada } \\
\text { Entrada }\end{array}$ & $\begin{array}{l}\text { Background } \\
\text { Background }\end{array}$ & $\begin{array}{l}46.0-56.0 \\
41.8-51.8\end{array}$ & \\
\hline $\begin{array}{l}\text { UC } \\
\text { UC }\end{array}$ & $\begin{array}{l}-0684 \\
-0685\end{array}$ & $\begin{array}{l}\text { Alluvium } \\
\text { Alluvium }\end{array}$ & $\begin{array}{l}\text { Downgradient } \\
\text { Downgradient }\end{array}$ & $\begin{array}{l}11.0-21.0 \\
15.0-25.0\end{array}$ & $\begin{array}{l}\text { Downgradient monitor } \\
\text { wells that can be used to } \\
\text { detect horizontal migration } \\
\text { of the plume. }\end{array}$ \\
\hline $\begin{array}{l}\text { UC } \\
\text { UC } \\
\text { UC } \\
\text { UC }\end{array}$ & $\begin{array}{l}-0506 \\
-0507 \\
-0508 \\
-0509 \\
-0510\end{array}$ & $\begin{array}{l}\text { Alluvium } \\
\text { Alluvium } \\
\text { Alluvium } \\
\text { Alluvium } \\
\text { Alluvium }\end{array}$ & $\begin{array}{l}\text { On-site } \\
\text { On-site } \\
\text { On-site } \\
\text { On-site } \\
\text { On-site }\end{array}$ & $\begin{array}{l}12.0-19.0 \\
10.0-20.0 \\
12.0-19.0 \\
12.0-22.0 \\
15.0-24.0\end{array}$ & $\begin{array}{l}\text { Monitor plume migration on } \\
\text { the site and down- } \\
\text { gradient of the tailings piles. }\end{array}$ \\
\hline $\begin{array}{l}\text { NC } \\
\text { NC } \\
\text { NC }\end{array}$ & $\begin{array}{l}-0503 \\
-0504 \\
-0512\end{array}$ & $\begin{array}{l}\text { Alluvium } \\
\text { Alluvium } \\
\text { Alluvium }\end{array}$ & $\begin{array}{l}\text { On-site } \\
\text { On-site } \\
\text { On-site }\end{array}$ & $\begin{array}{l}20.0-26.0 \\
14.0-18.0 \\
12.0-20.0\end{array}$ & \\
\hline $\begin{array}{l}\text { UC } \\
\text { uC }\end{array}$ & $\begin{array}{l}-0554 \\
-0702 \\
-0704\end{array}$ & $\begin{array}{l}\text { Entrada } \\
\text { Entrada } \\
\text { Entrada }\end{array}$ & $\begin{array}{l}\text { On-site } \\
\text { On-site } \\
\text { On-site }\end{array}$ & $\begin{array}{l}37.5-47.5 \\
55.0-65.0 \\
46.0-56.0\end{array}$ & \\
\hline
\end{tabular}


Table 2 Private well sampling locations at the NC and UC sites near Slick Rock, Colorado

\begin{tabular}{cccc} 
Well ID & $\begin{array}{c}\text { Well } \\
\text { description }\end{array}$ & $\begin{array}{c}\text { Formation of } \\
\text { completion }\end{array}$ & Sampling rationale \\
\hline SRK-01-0672 & Domestic & Unknown & Ensure protection of human health. \\
SRK-01-0805 & Domestic & Navajo & $\begin{array}{c}\text { Monitored during baseline risk } \\
\text { assessment analyses at a minimum. }\end{array}$ \\
SRK-01-0675 & Domestic & Alluvium & Ensure protection of human health. \\
\hline
\end{tabular}

Table 3 Surface water sampling locations at the NC and UC sites near Slick Rock, Colorado

\begin{tabular}{cll}
\hline $\begin{array}{c}\text { Surface water } \\
\text { location ID }\end{array}$ & \multicolumn{1}{c}{ Description } & \multicolumn{1}{c}{ Sampling rationale } \\
\hline SRK-01-0696 & $\begin{array}{l}\text { Dolores River sample collected } \\
\text { upgradient of NC site. } \\
\text { Dolores River sample collected } \\
\text { upgradient of UC site. }\end{array}$ & $\begin{array}{l}\text { Determine background surface water } \\
\text { quality of the Dolores River. }\end{array}$ \\
\hline SRK-01-0692 & $\begin{array}{l}\text { Dolores River sample collected } \\
\text { downgradient of NC site. }\end{array}$ & $\begin{array}{l}\text { Determine if former UMTRA Project } \\
\text { uranium processing activities have } \\
\text { affected the baseline surface water } \\
\text { quality of the Dolores River } \\
\text { downgradient of the tailings. }\end{array}$ \\
SRK-01-0694 & $\begin{array}{l}\text { Dolores River sample collected } \\
\text { downgradient of UC site. }\end{array}$ & \\
\hline
\end{tabular}


Table 4 Analytical constituents measured for water quality screening, Slick Rock, Colorado, sites

\begin{tabular}{|c|c|c|c|}
\hline Constituent & $\mathrm{MCL}^{*}$ & \multicolumn{2}{|c|}{ Constituents without MCLs } \\
\hline Cadmium $^{b}$ & 0.01 & Ammonium $^{\mathrm{b}}$ & Potassium ${ }^{c, d}$ \\
\hline Molybdenum ${ }^{b}$ & 0.1 & Calcium $^{b, c, d}$ & Sodium ${ }^{b, c, d}$ \\
\hline Nitrate $^{b, c, d}$ & 44.0 & Chloride $e^{b, c, d}$ & Sulfate $e^{b, c, d}$ \\
\hline Selenium $^{b}$ & 0.01 & Iron $^{b}$ & Vanadium $^{b}$ \\
\hline $\begin{array}{l}\text { Combined radium-226 } \\
\text { and radium-228 }\end{array}$ & $5.0^{\circ}$ & Gross alphab & Lead-210 \\
\hline $\begin{array}{l}\text { Combined uranium-234 } \\
\text { and }-238^{\mathrm{b}}\end{array}$ & $30.0^{\circ}$ & Magnesium ${ }^{b, c, d}$ & Thorium-230 \\
\hline $\begin{array}{l}\text { Net gross alpha } \\
\text { (excluding radon and } \\
\text { uranium) }\end{array}$ & $15.0^{\circ}$ & Manganese ${ }^{b}$ & Total dissolved solids ${ }^{e, d}$ \\
\hline
\end{tabular}

"Maximum concentration limits (MCL) expressed in milligrams per liter unless otherwise noted.

botential hazardous constituent related to uranium processing activities.

'Geochemical characterization.

${ }^{d}$ Constituent not analyzed in unfiltered samples.

"Picocuries per liter. 